\title{
Metode Pemecahan Masalah dengan Pendekatan Kontekstual untuk Meningkatkan Hasil Belajar Sejarah Indonesia di MAN 2 Banyuwangi
}

\author{
Matali \\ MAN 2 Banyuwangi, Indonesia \\ matali.s.pd.mm@gmail.com
}

$\begin{array}{ccc}\text { Received } & \text { Accepted } & \text { Published } \\ 01 / 07 / 2020 & 23 / 07 / 2020 & 31 / 07 / 2020\end{array}$

\begin{abstract}
The purpose of this study was to determine the Application of Problem Solving Methods with Contextual Approaches to improve the history of learning outcomes. This CAR was held in the even semester of $2017 / 2018$ in class X Religion MAN 2 Banyuwangi. Implemented with three cycles, with procedures: 1) planning, 2) implementing actions, 3) observation, 4) reflection. Data were analyzed using qualitative descriptive techniques. Prior to the implementation of CAR, the average class learning outcome was 66, indicating that learning class completion was not classical because there were still students who scored $<65$ as many as 8 students with a percentage of $19.04 \%$, students who scored $65-100$ as many as 34 students with grades a percentage of $80.9 \%$. After the CAR was carried out in cycle 3 , the results showed classically, student learning was complete, because students who scored 65-100 were 42 students with a percentage of $100 \%$. Therefore, the application of the Problem Solving Method with the Contextual Approach is able to improve the results of the History study, class X Religion even semester 2017/2018 MAN 2 Banyuwangi.
\end{abstract}

Keywords: Problem Solving Method, Contextual Approach, Historical Learning Outcomes.

\begin{abstract}
Abstrak Tujuan penelitian ini untuk mengetahui Penerapan Metode Pemecahan Masalah dengan Pendekatan Kontekstual mampu meningkatkan hasil belajar Sejarah Indonesia. PTK ini dilaksanakan pada semester genap tahun 2017/2018 di kelas X Agama MAN 2 Banyuwangi. Dilaksanakan dengan tiga siklus, dengan prosedur: 1) perencanaan, 2) pelaksanaan tindakan, 3) observasi, 4) refleksi. Data dianalisis dengan teknik deskriptif kualitatif. Sebelum dlaksanakan PTK, rata-rata hasil belajar kelas sebesar 66, menunjukkan tidak tuntas belajar secara klasikal karena masih ada peserta didik yang mendapat nilai $<65$ sebanyak 8 peserta didik dengan persentase $19,04 \%$, peserta didik yang medapat nilai 65-100 sebanyak 34 peserta didik dengan nilai persentase sebesar 80,9\%. Setelah dilaksanakan PTK pada siklus 3, hasilnya menunjukkan secara klasikal, belajar peserta didik tuntas, karena peserta didik yang mendapat nilai 65-100 sebanyak 42 peserta didik dengan persentase 100\%. Oleh karena itu, penerapan Metode Pemecahan Masalah dengan Pendekatan Kontekstual mampu meningkatkan hasil belajaran Sejarah Indonesia, kelas X Agama semester genap tahun ajaran 2017/2018 MAN 2 Banyuwangi.
\end{abstract}

Kata kunci: Metode Pemecahan Masalah, Pendekatan Kontekstual, Hasil Belajar Sejarah Indonesia. 


\section{PENDAHULUAN}

Pendidikan sejarah Indonesia memberikan banyak manfaat kepada peserta didik sebagai bekal untuk hidup bermasyarakat. Maka kedudukannya sangat strategis sehingga sangat penting untuk dipelajari. Sementara yang terjadi di lapangan sebaliknya. Seharusya menjadi mata pelajaran yang menarik bagi peserta didik. Namun kenyataannya banyak peserta didik cenderung menganggap pelajaran sejarah Indonesia tidak penting. Pembelajarannya tidak menarik, relatif banyak peserta didik yang menganggap sebagai pelajaran hafalan sekaligus membosankan dan dianggap kurang bermanfaat.

Berdasarkan studi pendahuluan diketahui bahwa evaluasi hasil belajar, ulangan harian peserta didik kelas X Agama, rata-rata hasil belajar kelas sebesar 66, secara klasikal tidak tuntas karena yang mendapat nilai $<65$ sebanyak 8 peserta didik dengan persentase $19 \%$. Peserta didik yang medapat nilai 65-100 sebanyak 34 peserta didik dengan nilai persentase sebesar 81\%. Penyebab rendahnya nilai hasil ulangan harian tersebut karena, (1) materi pelajaran disampaikan dengan metode, strategi yang kurang tepat, model pembelajaran yang umumnya masih bersifat konvesional, (2) guru dominan hanya mengandalkan penerapan metode ceramah dan tanya jawab ala kadarnya, (3) minat membaca peserta didik yang relatih rendah, (4) kemampuan peserta didik memahami konsep-konsep esensial ilmu sejarah Indonesia masih relatif rendah, (5) peserta didik kurang memahami makna, manfaat bagi kehidupannya atas materi yang dipelajari, (6) peserta didik kurang memiliki semangat, keberanian atau malas untuk menyampaikan pendapat, (4) Peserta didik mayoritas kurang kritis analitis .

Upaya megatasi permasalahan pembelajaran tersebut, diterapkan penelitian tindakan kelas (PTK), yang bersifat kolaboratif, didasarkan pada permasalahan yang muncul dalam pembelajaran. Penelitian tindakan kelas yang akan dilakukan adalah dengan menerapkan pembelajaran dengan Metode Pemecahan masalah. Metode Pemecahan Masalah adalah upaya untuk mendefinisikan masalah, mendesain pemecahan, mengkomunikasikan dan memformulasikan hasil, Pemecahan masalah merupakan salah satu metode pembelajaran yang dapat meningkatkan kualitas proses dan hasil belajar peserta didik. Metode Pemecahan masalah adalah pelaksanaan pembelajaran dengan menerapkan fase mendefinisikan masalah, men-Desain solusi, mem-Formulasikan hasil, dan meng-Komunikasikan hasil dengan target utama yaitu mewujudkan sosok peserta didik yang aktif, kreatif dan kritis.

Menurut Djamarah dan Zain (2002:103) penerapan metode pembelajaran Pemecahan masalah mengikuti langkah-langkah sebagai berikut. 1) Adanya masalah yang jelas untuk dipecahkan. 2) Mencari data atau keterangan yang dapat digunakan untuk memecahkan masalah tersebut. 3) Menetapkan jawaban sementara dari masalah tersebut. 4) Menguji kebenaran jawaban sementara tersebut. 5) Menarik kesimpulan. 
Berikut ini adalah kelebihan dan kelemahan metode Pemecahan masalah. Kelebihannya adalah; (1) melatih berfikir secara ilmiah, (2) memusatkan kegiatan pada murid (peserta didik), (3) sebagai alternatif metode yang dapat memperkaya metode yang selama ini sudah berkembang di madrasah, (4) dapat memotivasi peserta didik untuk belajar di kelas maupun di luar kelas dalam menghadapi dan memecahkan masalah secara terampil, (5) dapat mendororng peserta didik bergairah dalam belajar untuk mengembangkan kemampuan berfikir secara kreatif dan menyeluruh, (6) lebih memperdalam, memperkaya dan memperluas pandangan tentang sesuatu yang dipelajari, (7) membawa efek instruksional, (8) merangsang untuk mampu menjadi eksplorer, mencari penemuan terbaru, inventor, pengembang ide gagasan dan pengujian baru yang inovatif, desainer, mengkreasi rencana dan model terbaru, pengambilan keputusan, berlatih bagaimana menetapkan keputusan yang bijaksana, dan sebagai komunikator, mengembangkan metode dan teknik untuk bertukar pendapat dan berinteraksi. Kelemahannya adalah: (1) masalah yang diberikan hendaknya sesuai dengan tingkat perkembangan dan kemampuan peserta didik, (2) peserta didik hendaknya terlebih dahulu diberikan penjelasan tentang maksud dan kemampuan peserta didik, (3) peserta didik hendaknya terlebih dahulu diberikan penjelasan tentang maksud dan tujuan serta cara-cara memecahkan masalahyang dihadapi, (4) selain bimbingan guru secara kontinyu, hendaknya tersedia sarana pengajaran yang memadai serta waktu yang cukupuntuk memecahkan masalah yang dihadapi, (5) masalah yang dihadadapkan hendaknya bersifat ilmiah (Pasaribu dan Simandjuntak, 1986:114; Sudirman, 1991: 141-147; Kusmawan, 1998:1).

Pembelajaran kontekstual merupakan sistem pembelajaran yang didasarkan pada filosofi bahwa peserta didik akan belajar jika mereka mengetahui makna dari materi akademisnya dan mereka memahami makna kegiatannya di sekolah/madrasah. Suatu strategi pembelajaran yang menekankan pada proses keterlibatan siswa secara penuh untuk dapat menemukan materi yang dipelajari dan menghubungkannya dengan situasi kehidupan nyata, sehingga mendorong siswa untuk dapat menerapkannya dalam kehidupan mereka". Artinya bahwa dengan pendekatan kontekstual, siswa diberikan kesempatan secara penuh untuk mengkonstruksi pengetahuan yang telah diperoleh dari hasil pengalamannya ke dalam proses menemukan suatu konsep Sejarah, sehingga siswa merasa bahwa materi yang telah diperoleh dari pengalamannya masih berguna dan dapat membantu pemahamannya terhadap pembelajaran yang berlangsung. Hubungan kehadiran situasi kehidupan nyata dalam pembelajaran dengan menggunakan pendekatan kontekstual ini diharapkan dapat memunculkan dan meningkatkan kemampuan siswa yang berkaitan dengan antarkonsep Sejarah dengan kehidupan sehari-hari. Diharapkan kemampuan pemecahan masalah Sejarah dapat meningkat, sebagaimana bahwa permasalahan yang diberikan kepada siswa bukanlah 
soal yang biasa ditemuinya, melainkan terdapat tantangan dalam memilih dan menyusun strategi pemecahan masalah secara kontekstual (Sanjaya, 2006: 253).

Pembelajaran perlu dilakukan secara terus-menerus untuk mengetahui peserta didik perlu tahu apa atau peserta didik harus tahu apa (Depdiknas, 2002:16). Hal ini berarti dalam proses belajar mengajar peserta didik perlu tahu terlebih dahulu apa yang harus dicapai, tidak hanya belajar dengan hanya mendapat informasi dari guru, tetapi peserta didik bisa dilatih mencari sendiri pemecahan masalah secara kontekstual yang harus dipelajari dengan standar ketuntasan yang telah ditetapkan oleh guru sebagai fasilitator.

Kualitas pembelajaran adalah kualitas proses pembelajaran dan hasil belajar. Kualitas proses dapat diketahui dari keaktifan peserta didik dalam PBM. Kualitas hasil dapat diketahui dari tes hasil belajar atau ketuntasan hasil belajar. Ketuntasan hasil belajar adalah penguasaan penuh dari peserta didik terhadap bahan yang telah diajarkan untuk mengetahui sampai sejauh mana proses belajar mengajar mencapai ketuntasan hasil belajar maka perlu dilakukan tes hasil belajar (Arikunto,1989:228). Tujuan pendidikan yang ingin dicapai dalam suatu pembelajaran terdiri dari tiga aspek, yaitu bidang kognitif, afektif dan psikologis. Ketiga aspek tersebut merupakan satu kesatuan yang tidak terpisahkan yang harus tampak sebagai hasil belajar (Rosyada, 2004:60-73).

Penelitian terdahulu tentang penggunaan metode pemecahan masalah sebagaimana yang dilakukan oleh Kartini., et.al. (2013) menyimpulkan bahwa metode pemcahan masalah mampu meningkatkan aktifitas fisik, mental, emosional, dan hasil belajar siswa dalam pembelajaran matematika. Putera., et. al, (2015) disimpulkan bahwa penggunaan metode pemecahan masalah (problem solving) efektif dapat meningkatkan kemampuan berpikir kritis secara optimal pada mahasiswa Semester I Program StudiPendidikanEkonomi FKIP UM Metro pada Standar Kompetensi memahami persamaan akuntansi. Oleh karena itu metode pemecahan masalah patut digunakan dalam pembelajaran Sejarah Indonesia.

Tujuan penelitian ini adalah sebagai berikut. 1) Untuk mengetahui metode pemecahan masalah dengan pendekatan kontekstual mampu meningkatkan hasil belajar peserta didik dalam pembelajaran sejarah Indonesia. 2) Untuk mengetahui metode pemecahan masalah dengan pendekatan kontekstual mampu meningkatkan kemampuan kognitif, afektif dan psikomotorik peserta didik pada pembelajaran sejarah Indonesia.

\section{METODE}

Penelitian tindakan kelas (PTK) ini bersifat kolaboratif, dilaksanakan di MAN 2 Banyuwangi. Dilaksanakan pada semester ganjil tahun akademik 2017/2018. Subyek yang di teliti adalah 42 Peserta didik kelas X AGAMA. PTK ini erupakan suatu bentuk kerjasama antara praktisi (guru) dan peneliti yang memungkinkan adanya kesamaan pandangan, kesamaan 
pemahaman, kesepakatan terhadap suatu permasalahan, pengambilan keputusan yang demokrasi yang pada akhirnya terwujud kesamaan tindakan. Setiap peserta didik dikatakan tuntas belajarnya (ketuntasan individu) jika proporsi jawaban benar peserta didik $>65 \%$, dan suatu kelas dikatakan tuntas belajarnya (ketuntasan klasikal) jika dalam kelas tersebut terdapat $>$ 85\% peserta didik yang tuntas belajarnya (Depdikbud, 2001).

Rancangan PTK ini didasarkan pada permasalahan yang muncul dalam pembelajaran di kelas. Dilakukan dengan tiga siklus dan setiap siklus memuat empat tahapan. Setiap siklus akan dalaksanakan sesuai dengan perubahan yang dicapai.. Berpedoman pada refleksi awal, maka prosedur pelaksanaan PTK ini meliputi: 1) perencanaan, 2) pelaksanaan tindakan, 3) observasi, 4) refleksi dalam setiap siklus. Prosedur penelitian tindakan kelas dalam penelitian ini dapat digambarkan sebagai berikut.

\section{Bagan I: Prosedur penelitian tindakan kelas}

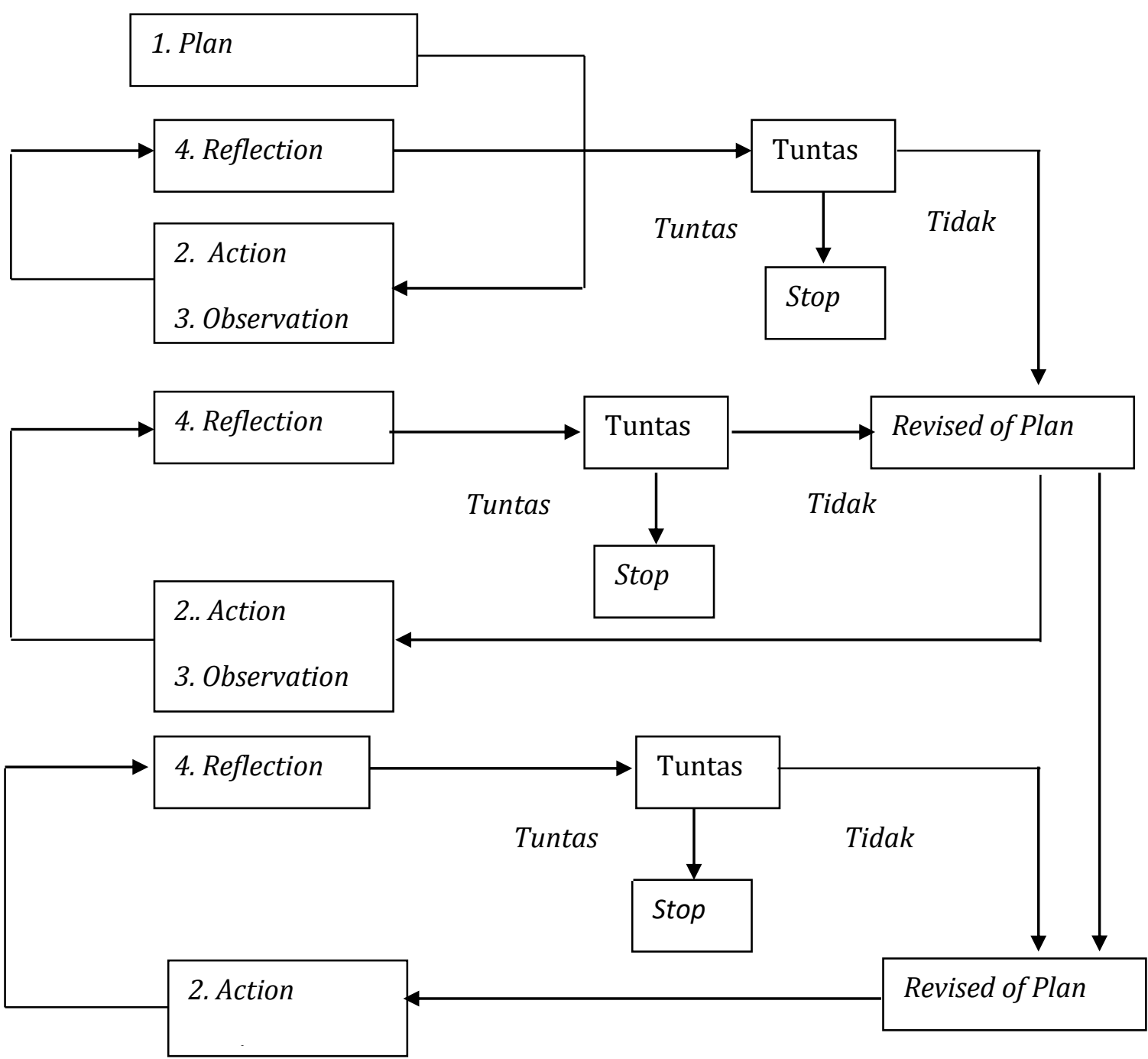




\section{Tehnik Analisis}

Teknik analisis data yang akan digunakan dalam PTK ini adalah teknik deskriptif kualitatif. Teknik tersebut untuk menggambarkan keadaan subyek penelitian, yaitu dengan menggambarkan kondisi subyek penelitian baik sebelum maupun pada saat penelitian di kelas atau pada akhir penelitian. Selain itu juga untuk mengetahui efektifitas penelitian (penerapan Pemecahan masalah), telah menunjukkan hasil yang maksimal atau belum.

\section{HASIL DAN PEMBAHASAN}

Hasil belajar sejarah Indonesia peserta didik kelas X Agama MAN 2 Banyuwangi menggunakan pembelajaran model Pemecahan masalah, diperoleh hasil belajar aspek kognitif, afektif, dan psikomotorik dapat dilihat pada tabel 2 sebagai berikut.

Tabel 2. Rekapitulasi Hasil Belajar Peserta didik dengan Model Pembelajaran Pemecahan masalah dengan pendekatan kontekstual.

\begin{tabular}{cccccccccc}
\hline Siklus & $\begin{array}{c}\text { Rata- } \\
\text { rata } \\
\text { hasil } \\
\text { belajar } \\
\text { kognitif }\end{array}$ & $\begin{array}{c}\text { Ketun- } \\
\text { tasan } \\
(\%)\end{array}$ & $\begin{array}{c}\text { peserta } \\
\text { didik } \\
\text { yang } \\
\text { tuntas }\end{array}$ & $\begin{array}{c}\text { Rata- } \\
\text { rata } \\
\text { hasil } \\
\text { belajar } \\
\text { afektif }\end{array}$ & $\begin{array}{c}\text { Ketun- } \\
\text { tasan } \\
(\%)\end{array}$ & $\begin{array}{c}\text { Neserta } \\
\text { didik } \\
\text { yang } \\
\text { tuntas }\end{array}$ & $\begin{array}{c}\text { Rata-rata } \\
\text { hasil belajar } \\
\text { psikomotor }\end{array}$ & $\begin{array}{c}\text { Ketun- } \\
\text { tasan (\%) }\end{array}$ & $\begin{array}{c}\text { pesert } \\
\text { a didik } \\
\text { yang } \\
\text { tuntas }\end{array}$ \\
\hline I & 68 & $83 \%$ & 35 & 70 & $78 \%$ & 33 & 69 & $75 \%$ & 32 \\
II & 75 & $86 \%$ & 36 & 73 & $82 \%$ & 34 & 72 & $82 \%$ & 34 \\
III & 78 & $100 \%$ & 42 & 78 & $96 \%$ & 40 & 79 & $93 \%$ & 39 \\
\hline
\end{tabular}

Sumber: Diolah dari Data Primer

Tabel 2 tersebut menunjukkan bahwa pada siklus I rata-rata hasil belajar pada aspek kognitif adalah 68, aspek afektif 70 dan aspek psikomotorik 69. Pada siklus II rata-rata hasil belajar pada aspek kognitif sebesar 75, aspek afektif 73, aspek psikomotorik 71. Pada siklus III diperoleh rata-rata hasil belajar pada aspek kognitif sebesar 78, afektif 78 dan psikomotor 79 . Rata-rata nilai pada siklus I tersebut terlihat relative rendah. Hal ini dikarenakan masih kurangnya minat siswa untuk belajar. Melalui penugasan Pemecahan masalah dapat melatih peserta didik dalam mengahadapi berbagai masalah sejarah Indonesia untuk dipecahkan sendiri atau bersama-sama. Dalam penelitian ini permasalahan tersebut dipecahkan melalui Lembar Kerja Peserta didik yang dibuat oleh peneliti dan gurunya. Pengambilan data diawali dengan pengambilan nilai, diperoleh nilai kognitif dari nilai tugas harian pada siklus I masih tergolong rendah, sehingga perlu diadakan tindakan untuk perbaikan proses belajar mengajar pada siklus II dan III. Rendahnya nilai rata-rata kelas juga menjadi salah satu sarat pelaksanaan 
penelitian tindakan kelas, hal ini juga mendasari pemilihan responden penelitian. Berdasar tabel 2. Dapat dibuatkan grafik sebagai berikut.

Grafik 1. Rekapitulasi Rata-Rata Hasil Belajar kognitif, afektif dan psikomotor Peserta didik menggunakan Metode Pemecahan masalah dengan pendekatan kontekstual

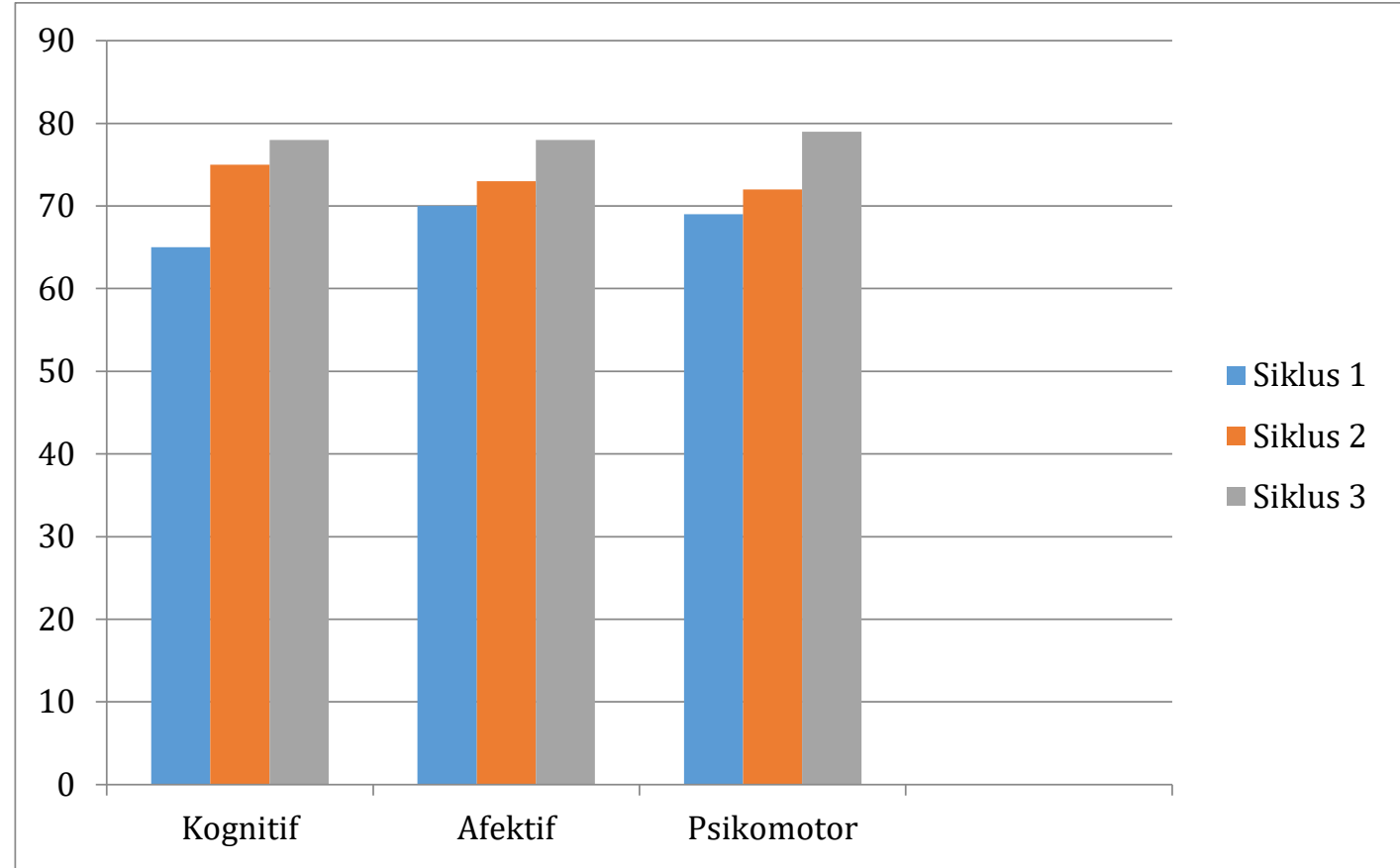

Sumber: Diolah dari Data Primer

Pada siklus I hasil belajar peserta didik pada aspek kognitif yang diperoleh peserta didik memiliki nilai rata-rata kelas belum memuaskan, hal dikarenakan peserta didik belum memahami Metode Pemecahan masalah. Peserta didik belum terbiasa dengan Metode Pemecahan masalah sehingga guru sebagai fasilitator dan motivator berupaya untuk memahamkan peserta didik agar dapat mengikuti kegiatan pembelajaran metode Pemecahan masalah. Kebiasaan peserta didik belajar dengan mendengarkan dan menerima informasi dengan guru menjadi belajar dengan banyak berfikir memecahkan masalah sendiri atau kelompok yang kadang-kadang memerlukan berbagai sumber, merupakan kesulitan tersendiri bagi peserta didik sehingga kondisi ini perlu dibiasakan.

\section{Ketuntasan Peserta Didik pada Aspek Koqnitif Secara Klasikal}

Ketuntasan belajar peserta didik pada aspek kognitif secara klasikal Siklus I, II, dan III diperoleh data sebagai berikut. 
Tabel 3 Ketuntasan Peserta didik pada Aspek Kognitif Secara Klasikal.

\begin{tabular}{crrrrrr}
\hline \multirow{2}{*}{ Nilai } & \multicolumn{3}{c}{ Jumlah Peserta didik } & \multicolumn{3}{c}{ Persentase (\%) } \\
& Siklus I & Siklus II & Siklus III & Siklus I & Sikus II & Sisklus III \\
\hline$<65$ & 7 & 4 & 0 & $17 \%$ & $10 \%$ & $0 \%$ \\
$65-100$ & 35 & 38 & 42 & $83 \%$ & $90 \%$ & $100 \%$ \\
Jumlah & 42 & 42 & 42 & $100 \%$ & $100 \%$ & $100 \%$ \\
\hline
\end{tabular}

Sumber : Diolah dari Data Primer

Tabel 3. tersebut menunjukkan bahwa ketuntasan belajar peserta didik aspek kognitif pada siklus I secara klasikal dikatakan tidak tuntas karena nilai 65-100 hanya 35 peserta didik dengan persentase 83\%. Sedangkan peserta didik yang nilainya $<65$ sebanyak 7 dengan persentae 17\%. Pada siklus II secara klasikal juga belum tuntas karena nilai 65-100 masih ada 38 peserta didik dengan persentase $90 \%$. Sedangkan peserta didik yang nilainya <65 sebanyak 4 dengan persentae 10\%, Pada siklus III secara klasikal dikatakan tuntas karena peserta didik yang mendapat nilai 65-100 sebanyak 42 peserta didik dengan persentase 100\%. Sedangkan peserta didik yang nilainya $<65$ tidak ada.

\section{Ketuntasan Peserta Didik pada Aspek Afektif Secara Klasikal}

Ketuntasan belajar peserta didik pada aspek Afektif secara klasikal Siklus I, II, dan III diperoleh data sebagai berikut.

Tabel 4. Ketuntasan Peserta didik pada Aspek Afektif Secara Klasikal.

\begin{tabular}{crrrrrc}
\hline \multirow{2}{*}{ Nilai } & \multicolumn{3}{c}{ Jumlah Peserta didik } & \multicolumn{3}{c}{ Persentase (\%) } \\
& Siklus I & Siklus II & Siklus III & Siklus I & Siklus II & Siklus III \\
\hline$<65$ & 9 & 9 & 2 & $21 \%$ & $21 \%$ & $4 \%$ \\
$65-100$ & 33 & 33 & 40 & $79 \%$ & $79 \%$ & $96 \%$ \\
Jumlah & 42 & 42 & 42 & $100 \%$ & $100 \%$ & $100 \%$ \\
\hline
\end{tabular}

Sumber: Diolah dari Data Primer

Tabel 4 tersebut menunjukkan bahwa ketuntasan belajar peserta didik aspek afektif pada siklus I secara klasikan dikatakan tidak tuntas karena nilai 65-100 sebanyak 33 Peserta didik dengan persentase 79\%. Sedangkan Peserta didik yang nilainya $<65$ sebanyak 9 peserta didik dengan persentase 21\%. Pada siklus II hasilnya sama dengan siklus I dan tidak ada peningkatan. Pada siklus III secara klasikal dikatakan tuntas karena peserta didik yang mendapat nilai 65-100 sebanyak 40 peserta didik dengan persentase 96\%. Sedangkan peserta didik yang nilainya $<65$ hanya 2 peserta didik dengan persentase $4 \%$. 


\section{Ketuntasan Peserta Didik pada Aspek Psikomotor Secara Klasikal}

Ketuntasan belajar peserta didik pada aspek Psikomotor secara klasikal Siklus I, II, dan III diperoleh data sebagai berikut.

Tabel 5. Ketuntasan Peserta didik pada Aspek Psikomotor Secara Klasikal.

\begin{tabular}{ccccccc}
\hline \multirow{2}{*}{ Nilai } & \multicolumn{3}{c}{ Jumlah Peserta didik } & \multicolumn{3}{c}{ Persentase (\%) } \\
& Siklus I & Siklus II & Siklus III & Siklus I & Siklus II & Siklus III \\
\hline$<65$ & 31 & 8 & 3 & $75 \%$ & $18 \%$ & $7 \%$ \\
$65-100$ & 11 & 34 & 39 & $25 \%$ & $82 \%$ & $93 \%$ \\
Jumlah & 42 & 42 & 42 & $100 \%$ & $100 \%$ & $100 \%$ \\
\hline
\end{tabular}

Sumber: Diolah dari Data Primer

Tabel 5. menunjukkan bahwa ketuntasan belajar peserta didik aspek psikomotor pada siklus I secara klasikal bisa dikatakan belum tuntas karena peserta didik yang mendapat nilai 65-100 sebanyak 11 Peserta didik dengan persentase 25\%. Sedangkan peserta didik yang nilainya $<65$ ada 31 peserta didik dengan persentase 75\%. Pada siklus II secara klasikal juga bisa dikatakan belum tuntas karena peserta didik yang mendapat nilai 65-100 sebanyak 34 Peserta didik dengan persentase $82 \%$. Sedangkan peserta didik yang nilainya $<65$ ada 8 peserta didik dengan persentase 18\%. Pada siklus III secara klasikal bisa dikatakan tuntas karena peserta didik yang mendapat nilai 65-100 sebanyak 26 peserta didik dengan persentase $92,85 \%$. Sedangka peserta didik yang nilainya $<65$ hanya 2 peserta didik dengan persentase $7,14 \%$.

Pada siklus II dan III hasil belajar peserta didik mengalami peningkatan pada perolehan rata-rata dari hasil belajar, karena peserta didik sudah mulai memahami dan membiasakan mengikuti pembelajaran dengan Metode Pemecahan masalah. Menurut Sudirman (1991:147) metode Pemecahan masalah merangsang pengembangan kemampuan berfikir peserta didik secara kreatif dan menyeluruh karena dalam proses pembelajaran,peserta didik banyak melakukan proses mental dengan meyoroti permasalah dari berbagai segi dalam rangka mencari pemecahannya. Peserta didik dikategorikan tuntas belajar jika mencapai skor $65 \%$ atau nilai 6,5. Kelas disebut tuntas belajar jika kelas tersebut terdapat $85 \%$ peserta didik yang telah mencapai daya serap $65 \%$.

\section{KESIMPULAN}

Berdasarkan hasil analisis data dapat disimpulkan bahwa: Penerapan Pembelajaran Metode Pemecahan masalah dengan pendekatan kontekstual mampu meningkatkan hasil belajar dan kemampuan kognitif, afektif dan psikomotorik peserta didik pada mata pelajaran 
sejarah Indonesia di MAN 2 Banyuwangi kelas X Agama Semester Genap Tahun Akademik 2017/2018. Hal tersebut didasarkan pada hasil siklus III yang menunjukkan secara klasikal, belajar peserta didik tuntas, karena peserta didik yang mendapat nilai 65-100 sebanyak 42 peserta didik dengan persentase 100\%. Penelitian ini bisa digunakan rujukan guru Sejarah Indonesia ketika menggunakan Metode Pemecahan masalah dalam proses pembelajaran sebagai salah satu alternative metode pembelajaran. Hasil penelitian ini bisa juga digunakan bahan masukan yang berguna dan juga sebagai umpan balik bagi upaya peningkatan kualitas belajar mengajar Sejarah Indonesia di masa sekarang dan yang akan mendatang.

\section{UCAPAN TERIMA KASIH}

Disampaikan terimakasih kepada Bapak Drs. H. Moh. Anwar, M.Pd.I selaku Kepala MAN 2 Banyuwangi yang telah memberikan ijin dilaksanakannya penelitian tindakan kelas ini. Terimakasih kepada Bapak Arif Setyawan selaku kolaborator dalam penelitian ini. Tidak lupa juga Terimakasih kepada Bapak H. Moh. Bisri Musthofa, M.Pd.I selaku kepala perpustakaan MAN 2 Banyuwangi. Kepada Segenap Bapak-Ibu Guru dan Karyawan-karyawati MAN 2 Banyuwangi yang tidak bisa disebutkan namanya satu-persatu, juga disampaikan terimakasih yang sebesar-besarnya atas segala bantuan dalam penelitian ini.

\section{REFERENSI}

Arikunto, S. (1989). Prosedur Pnelitian Suatu Pendekatan Praktek. Jakarta: Rineka Cipta.

Depdiknas. (2002). Kurikulum Berbasis Kompetensi. Jakarta: Balitbang.

Depdikbud, (2001). Kurikulum Pendidikan Dasar: Kurikulum KTSP SD/MI Mata Pelajaran Bahasa Indonesia. Puskur Depdiknas: Jakarta.

Djamarah, SB dan Zain, A. (2002). Strategi Belajara Mengajar. Jakarta: Rineka Cipta.

Kusmawan, U. (1998). Pengembangan Metode DDFK Problem Solving di SMU, Hasil studi. PSI-UT.

Kartini., et.al. (2013). Penerapan Metode Pemecahan Masalah Untuk Meningkatkan Aktivitas Siswa Dalam Pembelajaran Matematika Di Kelas III SDN 08 Nanga Potai. Jurnal Pendidikan dan Pembelajaran Khatulistiwa. Vol 2, No 4 April 2013. e-ISSN :Â 27152723. Universitas Tanjung Pura. Diakses pada 27 Juli 2017, dari http://jurnal.untan.ac.id/index.php/jpdpb/article/view/1756/0

Pasaribu dan Simanjuntak. (1983). Proses Belajar Mengajar. Bandung: Tarsito.

Putera., Et. Al, (2015). Metode Pemecahan Masalah Untuk Meningkatkan Kemampuan Berpikir Kritis. Jurnal JSS (Jurnal Studi Sosial). Vol 3, No 2 (2015). ISSN 2089-9335. Diterbitkan Oleh Ikatan Keluarga. Alumni Dan Program S2 Pendidikan IPS. UNILA. Diakses pada 27 Juli 2017, dari http://jurnal.fkip.unila.ac.id/index.php/ISS/article/view/9450

Rosyada, Dede. (2004). Paradikma Pendidikan Demokratis. Jakarta: Kencana. 
Sanjaya, W. (2006). Strategi pembelajaran berorientasi standar proses pendidikan. Jakarta: Kencana.

Sudirman. N. (1991). Ilmu Pendidikan. Bandung: Remaja Rosda Karya. 